\title{
The Dispute over Barefoot Gen (Hadashi no Gen) and Its Implications in Japan
}

\author{
Mizuno Norihito
}

\begin{abstract}
Barefoot Gen (Hadashi no Gen) is a comic series, the central theme of which is the author Nakazawa Keiji's experiences as an atomic survivor in Hiroshima during and after World War II, which became the subject of disputes in the summer and fall of 2013 in Japan. The Board of Education of the City of Matsue requested that all the elementary and junior high schools in the city move the comic books to closed shelves to restrict students' free access in December 2012, citing an excess of violent description as the reason. A local newspaper report about the education board's request published in August 2013 received broader attention from the major Japanese media and ignited disputes between journalists, critics and scholars, who engaged in arguments over two issues. Along with the propriety of the "closed shelf" request, the comic work's attitude to Japanese wartime conduct became an issue in dispute. This article clarifies the conflicting arguments that were exchanged by giving a detailed account of the dispute, arguing that this domestic event had significant implications for the historical controversy which remains a vexing diplomatic and domestic issue, even after seven decades have passed since the end of the Second World War.
\end{abstract}

Index Terms-Barefoot Gen (Hadashi no Gen), Japan, Historical Controversy, Nakazawa Keiji.

\section{INTRODUCTION}

A Japanese comic work became the center of domestic dispute in Japan in the summer and fall of 2013. The title of the comic work is Barefoot Gen (Hadashi no Gen). It is based on the author Nakazawa Keiji's experience as an atomic bomb survivor in Hiroshima during and after World War II [1]. On August 16th 2013, a local newspaper, San'in Chuo Shinpo, reported that the Board of Education of the City of Matsue, the capital city of Shimane Prefecture, had requested that all the municipal elementary and junior high schools transfer the comic series from open to closed shelves in December 2012 because of the presence of extreme descriptions of the wartime conduct of the Japanese military [2]. Major communications media soon responded to the local news report and almost unanimously took a critical line against the "closed shelf" request. As a result, ten days after the first newspaper report, the Board of Education announced that it had decided to withdraw the request [3].

The incident in late August thus ended with the virtual unconditional surrender of the local Board of Education to the major media powers, but it ignited several months of polemic among journalists, critics and scholars. The polemics revolved around three issues. First, the legal propriety of the

Manuscript received March 20, 2014; revised June 6, 2014.

Mizuno Norihito is with the Akita International University, Akita-shi, Akita 010-1292 Japan (e-mail: nmizuno@aiu.ac.jp). "closed shelf" handling of the comic was disputed from various points of view. Second, the educational appropriateness of the comic in a school library collection and its value as educational material were discussed. Third, the author Nakazawa's view of history, especially of Japanese wartime conduct and the issue of war responsibility as revealed in the volumes simultaneously became an issue in dispute.

The dispute over Barefoot Gen is thus another episode of historical controversy (rekishi ninshiki mondai). The historical controversy is today known to be one of the causes of discord between Japan and its East Asian neighbors. The best example is the controversy over Japanese history textbooks that has sporadically flared up since the early 1980s. The decades-long controversy over the Japanese prime ministerial visits to the Yasukuni Shrine and the recently-reheated territorial disputes are, needless to say, categorized as other cases of the controversy. It is simultaneously a domestic issue in Japan as scholars, critics and journalists are still discussing the various conflicting views of wartime history on the eve of the 70th anniversary of the end of the Second World War.

This article will first attempt to elucidate what conflicting arguments were exchanged and then demonstrate the complexity of the historical controversy. On the one hand, it is certainly a diplomatic issue as evidenced by the current state of Sino-Japanese and Japanese-Korean relations and the evident US concern over the discordance between its democratic allies in East Asia. On the other hand, the same dispute remains a domestic issue in Japan. As well as the domestic disputes over history textbooks and the Yasukuni Shrine, the dispute over the comic work became another example revealing that public consensus on the understanding of the wartime past is still absent in the country just one year before the 70th anniversary of the end of the war. The fragmentation of domestic views of the wartime past, which will not be easily solved, makes the historical controversy a seemingly endless international issue.

\section{BAREFOOT GEN (HADASHI NO GEN)}

Barefoot Gen is a comic series about a Japanese boy's years of hardship and survival as a Hiroshima atomic survivor during and after World War II. The author, Nakazawa Keiji (1937-2012), was an atomic bomb survivor in Hiroshima and the comic story is based on his childhood experiences before and after the end of the war [4]. The protagonist of the comic, Nakaoka Gen, was a second-grade elementary school student living with his six family members in Hiroshima in 1945. His hardships had begun before the 
atomic bombing. His family was alienated and harassed by their neighbors, the police and school teachers because of his father's antiwar politics. On August 6th 1945, his father, elder sister and younger brother were killed by the atomic bomb, while his pregnant mother bore a baby girl in the chaotic situation that arose immediately after the dropping of the bomb. In the few days before and immediately after the end of the war, Gen went through a series of hardships, including the death of his infant sister and mother. The story ends with Gen's departure for Tokyo after his graduation from junior high school in 1953 [1].

Nakazawa continued to work on the semiautobiographical comic story from 1973 until 1985. The comic started to appear in Weekly Shonen Jump (Shukan Shonen Janpu), published by a major Japanese publisher, Shueisha, in 1973. After it was cancelled by one of the most popular Japanese boys' manga magazines in 1974, primarily because of its relative unpopularity, it reappeared in a minor journal Shimin (Citizen) in 1975-1976 and continued in two other journals Bunka Hyoron (Culture Review) (1977-1980) and Kyoiku Hyoron (Education Review) (1982-1985) - until 1985 [4].

The comic work became widely known, not only in Japan but also abroad. It was published in book form and in paperback editions by several Japanese publishers and the aggregate circulation amounts to over 6,500,000 in Japan and over 10,000,000 around the world. It was translated and published in more than 20 countries [2]. It was also adapted for live action and animation movies and a TV drama [5], [6]. The Board of Education of the City of Hiroshima decided to adopt the comic as a teaching material for the peace education program for the third graders in elementary schools in 2012 [7]. NHK (Japan Broadcasting Corporation) reported in August 2013 on the use of the comic as a teaching material in more than 2,000 schools from primary to collegial levels in the United States [8].

What happened to Gen after he left Hiroshima in 1953 is unknown. Nakazawa planned to write a sequel after the end of the serialization in Kyoiku Hyoron in 1985. However, diabetes caused him to develop cataracts, which forced him to give up producing comics in 2009. In the news conference announcing his retirement as a cartoonist, he mentioned that he would leave the subsequent story of Gen's life to readers' imaginations. In December 2012, Nakazawa died of lung cancer [5].

\section{THE 2012 “CLOSED SHELF” REQUEST}

On December 17th, 2012, the executive office of the Board of Education of the City of Matsue requested that the principals of the local elementary and junior high schools restrict students' viewing of Barefoot Gen by taking such measures as moving it to a closed shelf and ensuring the supervision of students by librarians or teachers when they read the comics [9]. Since the reactions of the local schools to the request were not consistent, the principals asked the Board of Education for further explanations. On January 9th and 10th 2013, the executive members of the Board of Education attended meetings with the elementary and junior high school principals, requesting that they move the comic to closed shelves [9].
The Board of Education had already encountered challenges to the presence of the comic in the school libraries several months before making the "closed shelf" request. In late April and early May, a group of citizens repeatedly visited the Board of Education. According to a freelance journalist, Nagaoka Yoshiyuki, they are "right-wing" citizens and ex-executive members of a group called Citizens Against the Privileges of Korean Residents in Japan (Zaitokukai), founded in 2006 [9]. These "citizens" claimed that the comic could imbue children with fallacious perceptions of history, demanding that the Board of Education remove it from school libraries. In the conversations with the staff of the Board of Education, they resorted to such intimidating behavior as banging on the table and shouting. Nagaoka notes that the reaction of the staff members seemed resolute [9]. Others have suggested, however, that the staff members, one of whom repeatedly said she would call the police, treated the visitors clerically rather than resolutely [10]. Aside from such subjective matters, the important fact is that the Board of Education never bowed to the demand of the "citizens."

On August 24th, one of the abovementioned "citizens" petitioned the Matsue City Assembly against the comic. For an unknown reason, the report in San'in Chuo Nippo did not identify the petitioner as Nakajima Yasuharu. He had been a resident of Matsue but was now a resident of Kochi in Shikoku and presided over a political organization [11]. Nakajima appealed for the removal of the comic from school libraries on the grounds that it could give children an incorrect understanding of history [2]. Nagaoka gives a similar explanation, adding that the petition stated that the comic would exert a harmful influence on the cultivation of children's love of their own country and hometown, as decreed by the 2006 Fundamental Law of Education (Kyoiku Kihonho), which replaced the previous fundamental law enacted under the occupation of the Allied Powers in 1947 [11].

The city assembly did not adopt the petition. The Education and Public Welfare Committee (Kyoiku Minsei Iinkai) of the assembly started to deliberate the petition in September. The members of the committee had conflicting positive and critical - views of the comic itself, while they concluded that the propriety of the comic as a school library collection should be judged not by the city assembly but by the Board of Education. The plenary session of the city assembly also decided not to adopt the petition in early December 2012 [9].

However, Fukushima Ritsuko, who was the chair of the Board of Education when it made the "closed shelf" request, mentioned in an interview with Tokyo Shinbun on August 24th 2013 that the deliberation on the petition in the city assembly had convinced her that the Board of Education should take the measure [12]. In October, the Board of Education took a survey of 49 elementary in the city and found that 39 schools possessed the comic in their libraries, though another survey in August 2013 showed that all but five schools had it. The five executive members of the secretariat of the Board of Education, including the superintendent of education, simultaneously read all the volumes of the comics. Its depictions of sexual violence committed by Japanese soldiers in the 10th volume 
frightened and convinced them to make considerations for the children [9]. It should be especially noted here that the executive members of the Board of Education had not read all the volumes of the comic until that moment. Among the five members, four had never read the comic and the fifth had read only the first five volumes [2]. This fact reveals that the Board of Education declined the demand to withdraw the comic from the school libraries without knowing the content.

It is unlikely that the Board of Education made the final decision under pressure from outside. Nishigochi Yasuhiro, the chairman of the Committee for Intellectual Freedom in Libraries, part of the Japan Library Association, mentioned that he got the impression that the Board of Education surrendered to pressure from certain people [13]. However, Takeda Hajime, a reporter with one of the major Japanese newspapers, Asahi Shinbun, notes that the executive members' reading of the comic became the turning point. Reading the last volume, they were shocked by its depiction of sexual violence committed by Japanese soldiers and felt that they would hesitate to show children the comic [14]. As a matter of fact, Fukushima mentioned that she and other executive members of the secretariat of the Board of Education were shocked by such scenes of sexual violence [9]. As a result, despite the city council's decision to decline Nakajima's petition, the secretariat of the Board of Education retracted its previous position and decided that the object of restricted viewing should not only be the tenth volume but all the volumes of the comic in order to avoid the impression of censorship and "blackening"; it also decided that the "closed shelf" policy should be transmitted to school principals as a request (onegai) in order to avoid the impression of coercion [2]. The executive members made the decision without consulting the members of the Board of Education because they judged that calling a meeting of members was unnecessary since the decision was merely part of an administrative process [12].

The survey of the Board of Education on August 19th 2013 showed that most of the elementary and junior high schools complied with the request. Fourteen of 16 junior high schools stopped the perusal and borrowing of the comic by students and two others did not have the comic in their libraries. While only one of 33 elementary schools continued to allow students to read and borrow the comics, 28 schools stopped perusal and loan services. Three schools had no collection of the comic and one school answered that it had scrapped the comic [9].

\section{THE Dispute OVER BAREFOOT GEN}

It was not until late August 2013 that the "closed shelf" request received nationwide attention. In other words, the decision made by the local Board of Education in December 2012 did not receive wider attention for about eight months, at which point the mass media, for reasons unknown, started to pay attention. Hata Ikuhiko raised the question of why San'in Chuo Shinpo reported a month after the Board of Education made the request, noting that nationwide newspaper coverage followed the local report [2]. On August 16th, following the report in San'in Chuo Shinpo, Takeda Hajime's report on the request of the Board of Education appeared in Asashi Shinbun [14]. Hata's interpretation is perhaps correct because Goto mentioned on his Twitter feed that he was dispatched to Matsue immediately after the local report [2], [14]. On the same day, Mainichi Shinbun also reported that the comic had been placed on a closed shelf because of its violent depictions [15].

Four days later, the editorial articles of the two major newspapers criticized the request, which effectively marked the beginning of the dispute over the "closed shelf" request. The editorial article in Asahi Shinbun admitted that Barefoot Gen has been criticized for its brutal scenes as well as for its biased view of Japanese wartime conduct and of the responsibility of Emperor Showa (r. 1926-1945) during the war. It recognizes that the author's antiwar message has appealed to children and could provide a good opportunity for both children and adults to discuss those controversial issues [16]. Mainichi took the same stance. It concluded that the comic is worthy of being read, contending that the violent depictions are merely expressions of the reality of the war and the atomic bombing and offering the criticism that the excessive restriction of perusal could infringe on freedom of expression and deprive children of an opportunity for thought [17].

Local newspapers fell in step with those major papers. On August 21st, an editorial article in Tokyo Shinbun, a local paper published in the Tokyo metropolitan area, also admitted the presence of violent scenes but considered that the comic could provide an opportunity to think and talk about peace [18]. Kobe Shinbun similarly criticized the restricted access to the comic on the grounds that it could deprive children of a chance to study [19]. Local papers' criticisms of the request continued in the following few days. On August 22nd, an editorial article in Ryukyu Shinpo equated the "closed shelf" request with the Nazis' burning of books, warning that freedom of expression and the right to know have become endangered in Japan [20]. On August 23rd, an editorial article in Kyoto Shinbun made a similar argument against the request [21].

The critical media reports and opinions seemed to rouse public opinion and action against the "closed shelf" treatment of the comic. Chugoku Shinbun reported on August 25th that the Matsue City Board of Education had received 281 phone calls, emails and faxes by August 17th, most of which were critical of the Board of Education [22]. The Board of Education had eventually elicited 3,549 opinions between August 16th and September 12th, about 60 percent of which were against the "closed shelf" approach [12]. A call for support for a request to restore free access to the comic, launched on August 16th on the petition site Change.org, had obtained more than 6,000 signatures in two days [22]. Confronted with media and public criticism, the Board of Education conducted a survey of the principals of the 49 elementary and junior high schools in Matsue [9]. Tokyo Shinbun reported on August 24th that half of the principals of the junior high schools were against the "closed shelf" request and that half of the principals of the elementary school were against or asked for reconsideration of the request [9].

Under fire, the Matsue City Board of Education finally chose to withdraw the "closed door" request. As early as August 19th, Sanin Chuo Shinpo reported that the Board of Education would hold a meeting to discuss the "closed shelf" request by summoning the board members on $22 \mathrm{nd}$, but the 
meeting could not (or did not) reach a conclusion [23]. On the same day, the board also explained to the media the sequence of events that led to the "closed shelf" approach being decided in December 2012, and admitted that the brutal depictions led to the decision [24]. In the aforementioned Tokyo Shinbun interview of August 24th, Fukushima Ritsuko stated that the "closed shelf" request was made in consideration of the negative effect that brutal depictions would have on children rather than to restrict freedom of expression. She understood that her authority as a chairperson did not require consultation with the board members. She then admitted that she should have listened to the opinions of the schools and those of the members of the Board of Education [12]. Two days after the report, on August 26th, the Board of Education decided to formally withdraw the request [2].

It is not true, however, that the mass media unanimously took a critical stance towards the "closed shelf" request. In his column of August 21st, Abiru Rui, a senior staff writer on Sankei Shinbun, questioned whether the writers of the editorial articles of the three newspapers - Asahi, Mainichi and Tokyo - had really read all the volumes of the comic. Abiru understood that freedom of expression as guaranteed in the Japanese constitution tolerates such works as Barefoot Gen. He contended, however, that the issue of whether or not the comic is appropriate for school libraries is separate from the issue of freedom of expression. He answered his own question in the negative [24]. The editorial article in San'in Chuo Shinpo might give readers an ambiguous impression, because it stated that it is not difficult to understand the judgment made by the Board of Education that the treatment of the comic requires consideration for children [2]. An editorial article in another national newspaper, Yomiuri Shinbun, on August 25th expressed support for the "closed shelf" request in terms of educational considerations quite explicitly. The editorial article recognizes that the constitution does not tolerate restricted viewing of collections in public libraries, on the one hand. However, the article affirms that school libraries should not be discussed on the same level as public libraries, defending the idea that Matsue City Board of Education perhaps took the measure in consideration for the possible effects the comic might have on children [25].

Not only in the print media but also in audiovisual media some organizations and individuals entered the dispute, which continued even after the Matsue City Board of Education retracted the "closed shelf" request. As well as such print media as the aforementioned newspapers, the audiovisual media not only reported the "closed shelf" request but also broadcast individual comments - mostly by well-known individuals - on request. On August 22nd, on the daily morning show Mino Monta no Asazuba, broadcast by Tokyo Broadcasting System Television (TBS Television), the influential host of the show Mino Monta and other commentators appreciated that the comics express the misery of war and the importance of peace, making critical comments regarding the "closed shelf" treatment. One of the commentators, Kitagawa Masayasu, a professor at Waseda University and ex-governor of Mie Prefecture, discussed the "closed shelf" request from a procedural point of view. On the other hand, none of them made comments regarding the reasons why the Board of Education took such action [26]. Three days later, five guest commentators unanimously made critical comments about the "closed shelf" treatment on the weekly show broadcast by TBS Television, Sunday Morning. Some admitted that the comic leaves them with questions about the acceptability of the author's view of wartime history, but all recognized its value as a tool for teaching children the cruel reality of war and concluded that the "closed shelf" request should be retracted [27].

Appeals against the "closed shelf" request came from a number of organizations. On August 20th, the Shimane Prefecture Teachers' Union made a statement that warning that the "closed shelf" treatment of the comic could infringe on children's free access to information and requested the immediate retraction of the request to the elementary and junior high schools in Matsue City [28]. The Japan Library Association (JLA) problematized the "closed shelf" request from a legal perspective. The association issued a statement on August 22nd, requesting that the Shimane City Board of Education retract the "closed shelf" request. The association alleged that the restriction of children's access to the comic contradicted its 1979 declaration of the freedom of libraries as well as domestic and international laws relating to freedom of expression and free and equal access [13]. Article 13 of the UNICEF Convention on the Rights of the Child guarantees children's freedom of expression and free access to all kinds of information and ideas. This freedom should be restricted only with respect to others' rights and reputations and with respect to the protection of national security and public order, health and morals [29]. While the Board of Education questioned the brutal depictions out of concern for the development of the children, the association insisted that such restrictions should not be applied to the comic [13]. On August 23rd, the Japan Confederation of A- and H-Bomb Sufferers Organizations (Nihon Gensuibaku Higaisha Dantai Kyogikai) requested that the Shimane City Board of Education withdraw the "closed shelf" request, stating that there is no reason to restrict access to an internationally-renowned comic which tells the truth about the atomic bombing [30].

Meanwhile, some other organizations supported the "closed shelf" approach to the comic. A group of atomic survivors named the Society of Atomic Survivors Seeking Peace and Safety (Heiwa to Anzen o Motomeru Higakusha no Kai) sent a statement to the Matsue City Board of Education on August 22nd approving the "closed shelf" treatment on the grounds that the comic was colored with vulgar antinuclear sentiments and contained descriptions that were questionable as historical facts [31]. The Japanese Society for History Textbook Reform (Atarashii Rekishi Kyokaisho o Tsukurukai) in effect expressed its stance supporting the "closed shelf" treatment. On September 11th 2013, the president of the society, Sugihara Seishiro, submitted a petition to the Education Minister, Shimmura Hakubun, calling for the removal of the comic from public libraries. The society regarded the comic as harmful to the healthy growth of children. It called for a ban on children's viewing of the comic not only in school libraries but also in all public libraries. This more critical stance was based on four identifiable problems in the comics. First, the comics contain brutal depictions unconducive to the healthy growth of 
children. Second, keeping the comic in schools could contradict government guidelines for elementary school education (Gakushu Shido Yoryo), which require the fostering of respect for the emperor, as a result of the strong abuse of the emperor found in the comic volumes. Third, the comics' disrespect for the national anthem Kimigayo could also contradict government guidelines and educational laws. Fourth, the comic contains unsubstantiated descriptions of historical events and factual mistakes [32], [33].

Politicians and political parties also gave conflicting responses to the "closed shelf" treatment of the comic. Education Minister Shimomura of the Liberal Democratic Party mentioned on August 21st that educational considerations in terms of the growth of children should be required of school libraries, suggesting that the "closed shelf "request posed no legal problems [26]. On August 27th, one day after the Board of Education withdrew the request, Shimomura admitted that there was perhaps a procedural problem with the making of the "closed shelf" request. He continued, however, that this did not mean that the request was illegal, bringing into question the board's decision to entrust the treatment of the comic to each school [34]. On the other hand, the president of the opposition Democratic Party of Japan, Kaieda Banri, attended a conference of the Japan Teachers Union in Yokohama on August 25th, where he made the criticism that the "closed shelf" treatment meant nothing less than the closing of the country's eyes to its past [35]. Teruya Kantoku of the Social Democratic Party, a member of the House of Representatives, also took a critical stance towards the "closed shelf" approach in terms of freedom of expression and free access to information, as guaranteed in Article 12 of the Japanese constitution, in his column appearing on the homepage of the party on August 29th [36].

The dispute continued up to the end of 2013, and even beyond, though it seemed to lose media attention quite sharply after August 27th. Perhaps coincidently, between late September and early October, three monthly journals Seiron, Will and the Tsukuru - ran articles on the dispute. The fortieth anniversary issue of Seiron, appearing in November and published by Sankei Shinbun, offered a special feature on the comic, running six critical articles. The article by the editorial staff of the journal contended that the Matsue City Board of Education should retract its own retraction of the "closed shelf" request and that all the boards of education in Japan should remove the comic from school libraries. It reasoned, in a very similar way to the Japanese Society for History Textbook Reform, that the contents of the comic contradicted the official guidelines for elementary school education in several ways [37]. Author Izawa Man and journalist Mishina Junn pointed out that the essence of the dispute over the comic should have been whether or not the understanding of history in the comic was appropriate for school education, but the dispute was side-tracked by an issue of freedom of expression [38], [39]. The dispute that started in August 2013 provided the impetus for the publication of two similar titles - Hadashi no Gen o yonde mita and Hadashi no Gen o yomu. The author of the former, freelance journalist Goto Juichi, argues that the comic should be read by school children but also that the factual mistakes would have to be pointed out. With the clarification of facts and fictions, he argues, the comic would become a suitable educational material for elementary and junior high school children [40]. The contributors in the latter title seldom refer to the dispute itself. Kure Tomofusa, a critic who identifies himself as a feudalist, merely suggested that a dispute over educational appropriateness could occur in relation to other works beyond Barefoot Gen in terms of factual accuracy and morals [41].

\section{The IMPlicAtions OF THE DisPute}

In the dispute over the "closed shelf" request by the Matsue City Board of Education, conflicting views were exchanged over three issues. First, the legality of the request was disputed. The critics of the request considered that the Board of Education infringed students' freedom of expression and the free access to information guaranteed in domestic and international laws. The supporters of the request contended that, as an educational material, the comic contradicts official educational guidelines. They also pointed out the double standard of the mass media's application of children's freedom to the comic and to pornography [38]. Second, conflicting views were exchanged over the comic's propriety as an educational reading material. Those who were critical of the request more or less unanimously appreciated the value of the comic as an effective material for peace education. Those who took the opposite position were also supporters of children's restricted access to the comic, which they criticized for reflecting the author's biased and distorted views of history and the emperor and for its violent scenes. The problematic nature of the contents from their point view provided their rationale for alleging that the presence of the comic in public schools violated the official educational guidelines. Third, the accuracy and adequacy of the author's understanding of wartime history was disputed. Regarding this issue, those who shared a critical stance towards the "closed shelf" request did not necessarily share the same views about the author's understanding of history and Emperor Showa. In this respect, some admitted that the comic certainly contained controversial descriptions, though they did not consider that such questionable aspects undermined the value of the comic. Others did not even address whether or not the author's factual understanding was accurate. As mentioned above, for those on the opposite side, by contrast, the author's controversial understanding of history and the emperor's wartime responsibility was the most crucial reason for supporting the "closed shelf" request and restricting the presence of the comic in schools.

These three issues are in fact not separated but linked to each other. Regarding the first and second issues, the "closed shelf" request would be by no means free from controversy from legal points of view. Whether the comic is suitable for school libraries may be a matter which tends to result in an endless series of conflicting subjective arguments. Nevertheless, it could also be a legal matter in some aspects. Those who justified the "closed shelf" request would have to demonstrate its legality according to the Japanese constitution and the Convention on the Rights of the Child. Children's rights and freedom could be restricted in 
accordance with the domestic and international laws; whether their access to the comic could be the object of legal restriction should be discussed. Similarly, the critics of the request would have to make counter-arguments against the allegation that the presence of the comic contradicts the official educational guideline which the Japanese Supreme Court ruled in 1976 had legally binding force [42].

Criticism of the request would have to be legitimized in accordance with the School Library Law (Gakko Toshokanho) which stipulates that school libraries should contribute to school curriculums which are supposed to be formed in accordance with the official educational guideline [43].

Assuming that educational materials should (or even must) transmit accurate information and truths to students, a question posed about Barefoot Gen in terms of factual accuracy and interpretive adequacy could be related to the aforementioned legal and educational questions. Those who take a critical stance on the "closed shelf" request did not, but should, always respond to the accusations, made by the supporters of the request, about the comic's factual mistakes and biased views. Article 2 of the Fundamental Law of Education (Kyoiku Kihonho) stipulates that one of the purposes of education is to acquire a variety of knowledge and cultural understanding [44]. If such accusations identify a real problem, another question would be whether the comic could legally be either an appropriate school library resource or an educational material. In that case, the critics would have to demonstrate how they could still defend their stance on the comic. They would have to demonstrate that the comic carries accurate information and that its interpretation of history is not biased.

The three issues over the comic and its "closed shelf" treatment - legality, educational propriety, and factual accuracy and interpretive adequacy - are thus intertwined with each other, which makes it possible to say, in other words, that the issue of how to understand history - wartime history in this particular case - binds the other two issues. This dispute indicates that behind the difference stances towards the "closed shelf" request, there seem to be different views of history. The critics of the comics, who are more or less identical with those who supported the "closed shelf" treatment, refuse to recognize the Japanese wartime conduct, including the sexual violence, depicted in the comic as wholly or partially factual. They refuse to accept the comic's blaming of Japan for its foreign policy and consider its interpretation of the war in Asia and the Pacific to be one-sided or biased. They also strongly reject the comic's critical and condemnatory attitudes, derived from its view of history, towards the emperor, the national anthem and the national flag. Meanwhile, the supporters of the comic, who are more or less identical with those who criticized the "closed shelf" treatment, regard the comic as good educational material for teaching the truth about the misery of the war and the importance of peace. This should be interpreted as a sign that they wholly or partially share the comic's view of history. Despite its acknowledgement that there are conflicting arguments about Japanese wartime conduct and Emperor Showa's responsibility, the editorial article in Asahi Shinbun on August 20th appreciated the comics as valuable educational reading material [16]. This could possibly mean that the national newspaper basically shares the view of history in the comic. Their strong commendation of the comic as a teaching material for peace education perhaps indicates that Mainichi Shinbun and Tokyo Shinbun find nothing to question in the comic's understanding of wartime history [17], [18].

\section{CONCLUSION}

On the eve of the fiftieth anniversary of the end of the Second World War, Carol Gluck traced Japanese "historical consciousness" over more than four decades, from the beginning of the postwar period until the very beginning of the post-Showa (Heisei) period. She demonstrated that different schools and individuals had discussed the wartime past in different ways in postwar Japan. In other words, in the postwar decades, at least until the early 1990s, consensus over the interpretation of history was absent in Japan [45].

That absence continues to exist twenty years after Gluck's study was published in 1993, as we approach the eve of the seventieth anniversary of the end of the war. History is today one of the causes of diplomatic discord between Japan and its East Asian neighbors. The controversies over the Japanese prime ministerial visits to the Yasukuni Shrine, over the descriptions of Japanese wartime conduct in Japanese history textbooks and over the so-called "comfort women" during the war are all rooted in questions of what should be acknowledged as a historical fact and how wartime history should be understood, though it should be noted that those controversies tend to be used for political ends in the relevant countries. Yasukuni, textbooks and "comfort women" are simultaneously the causes of domestic controversies which have reached no conclusion in recent decades. The dispute over the treatment of a single comic about an A-bomb survivor is merely another case revealing the enduring fragmentation of Japanese interpretations of wartime history.

\section{REFERENCES}

[1] K. Nakazawa, Hadashi no Gen (Barefoot Gen), Tokyo: Chobunsha, 1975-1987.

[2] I. Hata, “Asahi ga mata 'tsukebi'shita 'Hadashi no Gen' ('Barefoot Gen' which Asahi 'set fire' on again),” Will, vol. 107, pp. 268-279, November 2013.

[3] Nihon Kyosanto. (August 2013). "Hadashi no Gen" etsuran seigen o Tekkai (The withdrawal of the restricted perusal of 'Barefoot Gen')" Shinbun Akahata (The Akahata). [Online]. Available: http://www.jcp.or.jp.akahata/aik13/2013-08-29/2013082903_01_0.ht $\mathrm{ml}$

[4] K. Nakazawa, Hadashi no Gen jiden, The Autobiography of Barefoot Gen, Tokyo: Kyoiku Shiryo Shuppankai, 1994.

[5] K. Omura, "Hadashi no Gen": Sosaku no shinjitsu ("Barefoot Gen": The Truth of Its Creation) Tokyo: Chuo Koron Shinsha, 2013.

[6] Hadashi no Gen (Barefoot Gen), (2007). [Online]. Available: http://www.youtube.com/watch?v=TPaBsfaF480; http://www.youtube .com/watch? $\mathrm{v}=1 \mathrm{a} 5 \_$_UmIw4Ws

[7] Hiroshima shiritsu gakko 'heiwa kyoiku puroguramu' yunittobetsu kyozai ichiran (The List of the Educational Materials of Each Unit for Hiroshima Municipal Schools' 'Peace Education Program'). (2013) [Online]. Available: http://www.city.hiroshima.lg.jp/../20130226kaigisiryougidai1gakune n.doc

[8] Sekai ga kyokan 'Hadashi no Gen' (The World Symphasize with 'Barefoot Gen'). (August 2013). [Online]. Available: http://www.nhk.or.jp/worldwave/marugoto/2013/08/0806.html 
[9] Y. Nagaoka, “"Hadashi no Gen' etsuran seigen daironso no kongo no yukue (The future outcome of the great dispute over 'Barefoot Gen'),' Tsukuru (Creation), vol. 43, no. 9, pp. 32-43, November 2013.

[10] Hadashi no Gen: Chosen burando Matsue Shikyoi no katte Shihodai ("Barefoot Gen": The saturnalia of the Korean brand Matsue City Board of Education). (April 2013). [Online]. Available; https://www.youtube.com/watch?v=y_heaEYOdRg;https://www.youtu be.com/watch?v=MvYYjpUj0Z0\#aid=P-u_B1_S6k4

[11] Y. Nakajima. (2013). Island koji and kochi, Japan will test. [Online]. Available: http://ameblo.jp/tinmiena/

[12] Boryoku bamen ni odoroki 'hairyo hitsuyo' (Surprise at violent scenes: 'Consideration is necessary'), Tokyo Shinbun. [Online]. Available: https://docs.google.com/file/d/0B471MozIm-g3M0JPYWFEZnVFSW c/edit?pli=1

[13] N. Yasuhiro. (August 2013). Nakazawa Keiji cho 'Hadashi no Gen' no riyo seigen ni tsuite (Regarding the restricted use of Nakazawa Keiji "Barefoot Gen')," Nihon Toshokan Kyokai (Japan Library Association). [Online]. Available: https://www.google.co.jp

[14] T. Hajime. (2013). Hajimaru on Twitter. [Online]. Availble: https://twitter.com/hajimaru2

[15] Kyokuto Burogu. (2013). Far Eastern Blog. [Online]. Available: http://finalvent.cocolog-nifty.com/fareastblog/2013/08/post-539d.htm

[16] Asahi Shibun. (August 20, 2013). 'Hadashi no Gen' etsuran seigen tekkai o (Withdraw the restricted perusal of 'Barefoot Gen'). [Online]. Available: http://www.asahi.com/shimen/articles/TKY201308190482.html

[17] Mainichi Shinbun. (August 20, 2013). Hadashi no Gen: Senso shiru kicho na sakuhin da (Barefoot Gen: An important work to know the war). [Online]. Available: http://mainichi.jp/opinion/news/20130820k0000m070105000c.html

[18] Tokyo Shinbun. (August 21, 2013). Hadashi no Gen: Kare ni heiwa o osowatta (Barefoot Gen: We Learnt Peace from him). [Online] Available: http://silmarilnecktie.wordpress.com

[19] Kobe Shinbun. (August 21, 2013). Hadashino Gen: Etsuran no seigen ga kyoiku nanoka (Barefoot Gen: Is restricted perusal educational?) [Online].

Available: http://www.kobe-np.co.jp/column/shasetsu/201308/0006268916.shtm

[20] Ryukyu Shinpo. (August 22, 2013). Hadashi no Gen: Mekakushi o shite nan ni naro (Barefoot Gen: What sake do they blindfold for). [Online].

Available: http://ryukyushimpo.jp/news/storyid-211401-storytopic-11.html

[21] Kyoto Shinbun. (August 23, 2013). Hadashi no Gen: Etsuran seigen subeki de nai (Barefoot Gen: Restricted perusal is not everything) [Online]. http://www.kyoto-np.co.jp/info/syasetsu/20130824_2.html

[22] Chugoku Shinbun. (August 23, 2013). Hadashi no Gen' etsuran seigen: Senso kara me wo somukeruna (The restricted perusal of 'Barefoot Gen': Don't avert eyes from the war). [Online]. Available: http://www1.chugoku-np.co.jp/Syasetu/Sh201308230076.html

[23] San'in Chuo Shinpo. (August 20, 2013). Zenkocho ni anketo: 'Tekkai' fukue saikento e (The questionnaires to all the school principals: Reconsideration including a possibility of withdrawal). [Online]. Available: http://houinet.blogspot.jp/2013/08/blog-post_22.html

[24] R. Abiru. (August 21, 2013). Hadashi no Gen wa donna honk a (what kind of book is Barefoot Gen?). Sankei Shinbun. [Online]. Available http://sankei.jp.msn.com/politics/news/130821/lc113082121040002-n 1. htm

[25] Yomiuri Shinbun. (August 25, 2013). Hadashi no Gen: Kyoikujo no hairyo o do kangaeruka (Barefoot Gen: How should educational consideration be made?). [Online]. Available: http://gisyo-104.blogspot.jp/2013/08/2013825_8260.html

[26] Mino Monta no Asazuba (Mino Monta's Asazuba). (August 22, 2013) [Online]. Available: http://www.youtube.com/watch?v=-zwXjiIdv20

[27] Sandei Moningu (Sundaay Morning). (August 25, 2013). [Online]. Available: http://www.at-douga.com/?p=8683

[28] Shimaneken Kyoshokuin Kumiai. (August 20, 2013). Matsue Shikyoi ni yoru 'Hadashi no Gen' no 'heika' sochi ni taisuru Kenkai (The opinion about the 'closed shelf' treatment of 'Barefoot Gen' by the Matsui Municipal Board of Education). [Online]. Available: http://www.google.co.jp/url

[29] The Convention of the Rights of the Child. [Online]. Available: http://www.ohchr.org/en/professionalinterest/pages/crc.aspx

[30] Asahi Shinbun. (August 24, 2013). Hadashi no Gen Jiyu ni yomasete: Nihon Hidankyo mo yosei (Let us read Barefoot Gen freely: Japan Confederation of A- and H-Bomb Sufferers Organizations also requests). [Outline]. Available: http://www.asahi.com/edu/articles/OSK201308240001.html
[31] Heiwa to Anzen o Motomeru Higbakusha no Kai (The Association for the Atomic Survivors Who Seek For Peace and Safety). Sho, chu, ko, gakko toshokan ni okeru 'Hadashi no Gen' heika sochi e no sansei ikensho (The statement to support the closed-shelf treatment of 'Barefoot Gen' in the libraries of Elementary, Junior High, and Senior High Schools). (August 22, 2013). [Online]. Available: http://www.realpas.com

[32] Sankei Shinbun. (September 11, 2013). 'Gen' wa Gakko Kyoikuho ni ihan: Tsukurukai ga Monkasho ni tekkyo yosei ('Gen' violates the School Education Law: The Japanese Society for History Textbook Reform requests the Ministry of Education, Culture, Sports, Science, and Technology for removal). [Online]. Available: http://sankei.jp.msn.com/life/news/130911/edc13091115490004-n1.ht $\mathrm{m}$

[33] S. Sugihara. (September 11, 2013). 'Hadashi no Gen' no kyoiku genba kara no tekkyo o motomeru yosei (The request to remove 'Barefoot Gen' from schools). Atarashii Rekishi Kyokasho o Tsukurukai (Japanese Society for History Textbook Reform). [Online] Available:

https://www.facebook.com/Tsukurukairekishi/posts/66125879389921 1

[34] Shimomura Monbu Kagaku Daijin kishakaiken eizoban (The video version of the news conference of Education Minister Shimomura). Monbu Kagakusho (Ministry of Education, Culture, Sports, Science, and Technology). (August 27, 2013). [Online]. Available: http://www.mext.go.jp/b_menu/daijin/detail/1338941.htm

[35] Hadashi no Gen' etsuran seigen o hihan: Minshu, Kaieda daihyo Nikkyoso Teiki Taikai (The criticism of the restricted perusal of 'Barefoot Gen': The president of the Democratic Party Kaieda in the regular meeting of Japan Teachers Union). Sankei Shinbun. (August 25, 2013). [Online]. Available: http://sankei.jp.msn.com/politics/news/130825/stt13082520020001-n 1.htm

[36] K. Teruya. (August 29, 2013). Manga 'Hadashi no Gen' to 'Shiru kenri (Comic 'Barefoot Gen' and Freedom of Speech)'. Shaminto (The Social Democratic Party). [Online]. Available: http://www5.sdp.or.jp/special/kenpo/104teruya.htm

[37] S. Henshubu, "Mondai shin o ikkyo kokai: koredemo kodomotachi ni yomasemasuka? (The whole opening of the problematic scenes: Do you still let your children read?)," Seiron, no. 502, pp. 54-61, November 2013.

[38] M. Izawa, "Ainaki shikan wa kuni o horobosu (The view of history without patriotism ruins a country)," Seiron, no. 502, pp. 62-71, November 2013

[39] J. Mishina. "Matsueshi Kyoi wa naze meiso shitanoka: soshite kodomotachi ga gisei ni naru (Why did the Matsue Municipal Board of Education wander? Children are then victimized)," Seiron, no. 502, pp. 72-81, November 2013.

[40] J. Goto, “'Hadashi no Gen' o yondemita (I Read 'barefoot Gen')," Tokyo: Kosumikku Shuppan, 2013

[41] T. Kure, "Chinpuka sareta seigi no waku o koete: 'Hadashi no Gen' o yominuku tame ni (Beyond the framework of the obsolete justice: For perusing Barefoot Gen)," "Hadashi no Gen" o yomu (Reading Barefoot Gen), Tokyo: Kawade Shobo Shinsha, 2014, pp. 46-53.

[42] Gakushu Shido Yoryo o meguru kyoiku saiban (Educational trials on the Education Guidelines). Monbu Kagakusho 8Ministry of Education, Culture, Sports, Science, and Technology). [Online]. Available: http://www.mext.go.jp/b_menu/hakusho/html/others/detail/1318314.h tm

[43] Gakko Toshokanho (School Library Law). [Online]. Available: http://law.e-gov.go.jp/htmldata/S28/S28HO185.html

[44] Kyoiku Kihonho (Fundamental Law on Education). [Online] Available: http://law.e-gov.go.jp/htmldata/H18/H18HO120.html

[45] C. Gluck, "The past in the present," Postwar Japan as History, Berkeley \& Los Angeles, CA: University of California Press, 1993, pp.64-95.

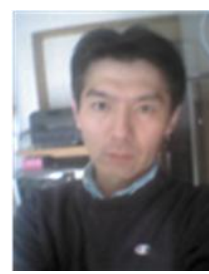

Mizuno Norihito has received Ph.D. He is an professor in the Global Studies Program at Akita International University, Akita, Japan. He was born in Nagoya, Japan and graduated from the Faculty of Law of Keio University, Tokyo, Japan. He earned Ph.D. in history at the Ohio State University, Columbus, OH, USA. His field of specialty is Japanese-East Asian relations, especially Sino-Japanese relations. $\mathrm{He}$ is currently working on Japanese communities and educational institutions in China during the modern period. 